\title{
Commentary \\ Complicating Gender, Sport, and Social Inclusion: The Case for Intersectionality
}

\author{
Gamal Abdel-Shehid ${ }^{1, *}$ and Nathan Kalman-Lamb ${ }^{2}$ \\ ${ }^{1}$ School of Kinesiology and Health Science, York University, Toronto, ON M3J 1P3, Canada; E-Mail: gamal@yorku.ca \\ 2 Trinity College of Arts \& Sciences, Duke University, Durham, NC 27710, USA; E-Mail: nathan.kalman.lamb@duke.edu \\ * Corresponding author
}

Submitted: 6 April 2017 | Accepted: 20 April 2017 | Published: 29 June 2017

\begin{abstract}
The following opinion piece concerns a reading of the work of Angela Davis and its application to the research on sport and social inclusion. It has the following aims: first, we use her work to argue that racism, as constituted via economics, helps to construct gender; second, we suggest that research on sport and social inclusion would do well to consider the work of Davis in forming a more complex reading of what it means to invite the participation-or inclusion-of women and girls in sport, both racialized and non-racialized.
\end{abstract}

\section{Keywords}

class; gender; race; social inclusion; slavery; sport

\section{Issue}

This commentary is part of the issue "Sport for Social Inclusion: Questioning Policy, Practice and Research", edited by Reinhard Haudenhuyse (Vrije Universiteit Brussel, Belgium).

(C) 2017 by the authors; licensee Cogitatio (Lisbon, Portugal). This article is licensed under a Creative Commons Attribution 4.0 International License (CC BY).

\section{Introduction}

The following opinion piece concerns a reading of the work of Angela Davis and its application to the research on sport and social inclusion. It has the following aims: first, we use her work to argue that racism, as constituted via economics, helps to construct gender; second, we suggest that research on sport and social inclusion would do well to consider the work of Davis in forming a more complex reading of what it means to invite the participation - or inclusion - of women and girls in sport, both racialized and non-racialized.

In making such an argument, we avoid the normal trend of reading identity in singular fashion-i.e., divorced from other identity categories. (e.g., gender, race). In doing so, we call for a more sustained discussion of the economy and processes of racialization to a discussion of gender. This approach has been referred to elsewhere as intersectionality ${ }^{1}$ and is in keeping with the general argument in Out of Left Field (Abdel-Shehid \& Kalman-Lamb, 2011), where we argued that both sport and identity sport should be read intersectionally-that is within broader social structures.

This argument challenges the pervasive reading of sport as a distinct, even unique, social sphere bracketed from society at large. It suggests that a re-reading of "gender and sport" with an eye on racialization and economics offers a significantly richer reading. As such, this argument has significant implications for our understanding of social inclusion with respect to gender and sport, both past and present.

\section{Angela Davis as Intersectional Theorist}

A brief look at Davis's contribution and its potential ramifications for the study of social inclusion will be of use

\footnotetext{
${ }^{1}$ While there is much literature on this term currently, we note that it was Patricia Hill Collins who elaborated this term in her work Black Feminist Thought (2000). Our reading of the concept is quite different from that of Hill Collins, since she chooses a more Afrocentric approach, whereas ours, borrowing from Davis, is informed by a historical materialist understanding of "race" and therefore gender.
} 
here $^{2}$. We do this with the full knowledge that she has not written about sport and has not been cited in work pertaining to sport history or sociology, much less the emerging field of sport and social inclusion. Davis was and is a noted feminist scholar and political activist. It is a little known fact that she studied with Herbert Marcuse in Boston and completed her doctoral work under the supervision of Theodor Adorno in Germany. This would in part explain her orientation towards Marxism and dialectics more broadly as a framework to understand social phenomena such as race and gender.

Her particular contribution, especially in Women, Race and Class (Davis, 1983) is to suggest that not only is the idea of race connected to the economic needs of plantation slavery and its aftermath, but that normative ideas of gender were produced in the same context. That is, at the very birthplace of white ideas about gender, what has been called the ideology of femininity was not possible without the backdrop and the subsequent "degendering" of enslaved, in this case, Black women (and men). In other words, racialized and gendered categories of identity were interwoven and also highly dependent on the surrounding economic context.

Davis' implicit argument, something we make explicit here, is that enslaved people were not only written out of the category human, they were simultaneously written out of the category of gender. This is not to say that there were not forms of sexual differentiation, but it is to say that understanding such differentiation as having specific social attributes, which is what we have come to know as "gender" did not apply to enslaved people. In other words, gender was a concept reserved for whites, both men and women.

For example, during plantation slavery in the United States, Davis notes there was no belief that slave women and slave men should do different tasks. ${ }^{3}$ Since the goal of slavery was to obtain the maximum profit possible, there was little labour that enslaved women were not required to do. As such, the economic value of enslaved Black women was equal to or greater than that of Black men. As Davis writes (1983, p. 10): "Slaveowning industrialists used men, women and children alike, and when planters and farmers hired out their slaves, they found women and children in as great demand as men."4

In addition to this, Black women in slavery, as Davis points out, suffered a special form of persecution, known as sexual torture, or rape. She writes $(1983$, p. 7):

As females, slave women were inherently vulnerable to all forms of sexual coercion. If the most violent punishments of men consisted of floggings and mutilations, women were flogged and mutilated, as well as raped.
This practice of sexual torture, as Davis notes, was not in any way about sexual desire. Rather, it was intimately tied to the mode of production and the slaveholder's attempts to establish and maintain economic superiority. Davis says as much when she notes that "the special abuses inflicted on women thus facilitated the ruthless economic exploitation of their labour," (1983, p. 7). In addition to establishing economic control over enslaved women, one of the effects of such a practice was to render Black women outside of the bounds of normal, socially constructed (i.e., white) gender and sexuality. By maintaining Black women at the level of beasts, forms of economic exploitation were much easier to pursue. This is why Davis can make what seems to be an odd claim on the surface, which is that "Racism draws its strength from sexual coercion."

\section{Ramifications for the Study of Gender, Sport, and Social Inclusion}

This of course has significant ramifications for the study of women's athletics in the early twentieth century and into the present. For, after all, is not the question of the social inclusion of women in sport in part the story of not being permitted access to the realm of masculinity that is sport? This problem is turned on its head if we acknowledge that histories of slavery and racialization have figured Black women as essentially physical, active, labouring subjects. In other words, the very construction of women's sport in its engenderment as women's sport is in and of itself exclusionary both based on its inherent denial of the legitimacy concomitant with men's sport (seen as sport proper) and on a fundamentally white iteration of gender that posits a stark distinction between the masculine and feminine in the realm of physicality.

In Out of Left Field (Abdel-Shehid \& Kalman-Lamb, 2011), we included Davis because we noted that the historical studies which look at turn-of-the century women's and men's sport contain an insufficient understanding of the intersections of the various identity categories and the emergence of these identity categories on economic processes. This is still true in the historical literature. Thus, for example, while there is some literature on women's athletics at the turn of the century, including the work of Susan Cahn (2015), Vertinsky and Captain (1998) and Captain (1991), it seems to us that these histories are limited in that they fail to account for the intersection of gender, race and economics. Rather, they read the details of history as somewhat independent of socio-economic processes. For example, in Gwendolyn Captain's (1991) essay “Enter Ladies and Gentlemen of Color" some attention is paid to the ways in which early Black women in sport attempted to carve out a certain

\footnotetext{
${ }^{2}$ A more detailed treatment of Davis' contribution is found in Out of Left Field, chapters 6 and 8.

${ }^{3}$ Davis notes that this also applied to white women during slavery.

${ }^{4}$ Davis (1983, p. 10), citing Karl Marx, notes that white women's labour was used in very similar ways in the 1800s in England, where "women are still occasionally used instead of horses for hauling canal boats, because the labour required to produce horses and machines is an accurately known quantity, while that required to maintain the women of surplus population is below all calculation [i.e., far less expensive.]"
} 
modicum of respectability. Yet a reading of Davis (1983) shows that this very attempt to enter into respectability was a reaction to the disparaging tropes about Black women and men which emerged in slavery and the postslavery period, also known as Reconstruction. Moreover, while the essay "More Myth than History" (Vertinsky \& Captain, 1998) is a very valuable piece of scholarship on the ways that Black women in sport have been represented throughout the course of the twentieth century, it pays no attention to the way economics past and present influence such representations. Our focus, on the other hand, is to expose the terrain that enabled the idea of women's athletics in the first place in order that the analysis by Vertinsky and Captain can be used to study white women athletes also. This is because we are arguing that identity is formed not only through difference, but more crucially via economic processes.

As in the past, this contribution also has significant ramifications for the study of sport and social inclusion in the present. As such, we made a similar argument to this effect in our piece on Bend it Like Beckham (AbdelShehid \& Kalman-Lamb, 2015), where we noted that to celebrate the film as an example of the inclusion of South Asian women in soccer is to ignore the very exclusionary practices of the mode of production and its highly liberal ("inclusive") variant, multiculturalism. In that essay, we noted the economic (as opposed to cultural) nature of multiculturalism and read the film not only as an example of what Giardina calls "stylized hybridity," but also as a celebration of assimilation which has deep roots in the economic, both in Britain and Canada. Thus, while we do not wish to discount or dismiss the heroic contribution individual women have made in sport, we maintain our emphasis on the terrain that enabled such contributions. Without a focus on structure as at least in part coconstitutive, it would be impossible for historians or sociologists of social inclusion to note how women's sport has emerged and why it has taken certain forms both in the past and present.

\section{Conclusion}

All of this is to underscore the importance of economically intersectional analysis for the study of women's ath- letics in the early twentieth century and beyond. Namely, it forces us to consider what we have argued elsewhere (Abdel-Shehid \& Kalman-Lamb, 2011, 2015), which is that as long as racism and economic inequality persists, a more intersectional or radical understanding of the concept of gender inclusion in sport would be helpful. This is because normative (white) ideas of gender break down in a racialized framework. Thus, a greater attention to intersectional readings of race, gender, and economic formation would ask us to remain attentive to who is being included in sport and what that inclusion accomplishes.

\section{Conflict of Interests}

The authors declare no conflict of interests.

\section{References}

Abdel-Shehid, G., \& Kalman-Lamb, N. (2011). Out of left field: Social inequality and sports. Halifax, NS: Fernwood Books.

Abdel-Shehid, G., \& Kalman-Lamb, N. (2015). Multiculturalism, gender, and Bend it Like Beckham. Social Inclusion, 3(3), 142-152.

Cahn, S. (2015). Coming on strong: Gender and sexuality in women's sport. Champaign, IL: University of Illinois Press.

Captain, G. (1991). Enter ladies and gentlemen of color: Gender, sport, and the ideal of African American manhood and womanhood during the late nineteenth and early twentieth centuries. Journal of Sport History, 18(1), 81-102.

Davis, A. (1983). Women, race and class. New York: Vintage.

Hill Collins, P. (2000). Black feminist thought: Knowledge, consciousness, and the politics of empowerment. New York: Routledge.

Vertinsky, P., \& Captain, G. (1998). More myth than history: American culture and representations of the Black female's athletic ability. Journal of Sport History, 25(3), 532-561.

\section{About the Authors}

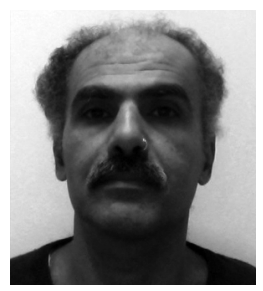

Gamal Abdel-Shehid is Associate Professor in the School of Kinesiology and Health Science at York University where he teaches courses on sport and social inequality/justice as well as courses on the nature of mind and consciousness. He is also appointed to (and past Director) of the Graduate Programme in Social and Political Thought where he regularly teaches the Frantz Fanon Seminar. He is the author of two books: Who Da Man? Black Masculinities and Sporting Cultures and (with Nathan Kalman-Lamb) Out of Left Field: Social Inequality and Sports. 


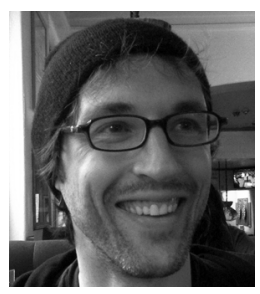

Nathan Kalman-Lamb is a Lecturing Fellow in the Thompson Writing Program at Duke University where he teaches on social inequality and sports. He is the co-author (with Gamal Abdel-Shehid) of Out of Left Field: Social Inequality and Sports and has published on multiculturalism, race, and sport in journals such as Topia, Social Identities, and Social Inclusion. 